\title{
Extraction of Quercetin from Nothopanax scutellarium Leaves via Ionic Liquid-based Microwave-assisted Extraction
}

\author{
Ika Aulia Rahmi' , Mahdi Jufri², Abdul Mun'im"*
}

Ika Aulia Rahmi ${ }^{1}$, Mahdi Jufri², Abdul Mun'im ${ }^{3, *}$

'Graduate Program of Herbal, Faculty of Pharmacy, Universitas Indonesia, Depok 16424, INDONESIA.

${ }^{2}$ Department Pharmaceutical Technology and Drug Development, Faculty of

Pharmacy, Universitas Indonesia, Depok 16424, INDONESIA.

${ }^{3}$ Department of Pharmacognosy and Phytochemistry, Faculty of Pharmacy, Universitas Indonesia, Depok 16424, INDONESIA.

\section{Correspondence}

\section{Abdul Mun'im}

Department of Pharmacognosy and Phytochemistry, Faculty of Pharmacy, Universitas Indonesia, Depok 16424, INDONESIA.

E-mail: munim@farmasi.ui.ac.id History

- Submission Date: 09-08-2020;

- Review completed: 23-08-2020;

- Accepted Date: 09-09-2020.

DOI : 10.5530/pj.2020.12.207

Article Available online

http://www.phcogj.com/v12/i6s

\section{Copyright}

(C) 2020 Phcogi.Com. This is an openaccess article distributed under the terms of the Creative Commons Attribution 4.0 International license.

\begin{abstract}
Introduction: Nothopanax scutellarium leaves have been used in Indonesian traditiona medicine to treat several diseases. Previous studies used conventional extraction methods with large volumes of organic solvents, long extraction times, and low levels of quercetin content. This study was aimed to identify the optimal solvent among different ionic liquids that has the highest quercetin content. Methods: Ionic liquids including 1-butyl-3-methylimidazolium bromide, 1-butyl-3-methylimidazolium tetrafluoroborate, 1-butyl-3-methylimidazolium chloride, 1-butyl-3-methylimidazolium hydrogen sulfate, and 1-hexyl-3-methylimidazolium bromide, for extracting quercetin from $N$. scutellarium leaves using microwave-assisted extraction under the following conditions: ratio, 1:10; operation time, $10 \mathrm{~min}$; and power, $10 \mathrm{~W}$. Then, quercetin was fractionated using ethyl acetate and separated using $0.01 \mathrm{~mol} / \mathrm{L}$ sodium bocarbonate, dipotassium phosphate or sodium cloride. The total flavonoid content was determined using a UV-Vis spectrophotometer, and quercetin content was determined using HPLC. Results: Extraction with 1-butyl-3-methylimidazolium chloride using $\mathrm{NaCl}$ as the separation salt was associated with the highest total flavonoid $(360.57 \mathrm{mg} / \mathrm{g})$ content among the ILs, whereas 1-butyl-3-methylimidazolium tetrafluoroborate combined with sodium chloride generated the highest quercetin content $(26.13 \mathrm{mg} / \mathrm{g})$. Conclusion: 1-butyl-3-methylimidazolium tetrafluoroborate is the optimal solvent for extracting quercetin from $N$. scutellarium leaves. Key words: Flavonoid, Ionic liquid, Green extraction, Green technology, Mangkokan Leaf.
\end{abstract}

\section{INTRODUCTION}

Mangkokan (Nothopanax scutellarium Merr.) leaves have been used traditionally to treat various conditions such as alopecia, wounds, anuria, and body odor. ${ }^{1}$ Based on prior studies, mangkokan leaves can promote hair growth. ${ }^{2-4}$ Although the mechanism of this effect is unclear, the activity of mangkokan leaves was believed to be attributable to its flavonoid content.

Quercetin is a major flavonoid in most plant extracts. ${ }^{5}$ Quercetin is known for anti-oxidant, anti-inflammatory, anti-obesity, anti-hypertensive, vasodilatory, anti-hypercholesterolemic, antiatherosclerotic, anti-bacterial, and anti-biofilm effects. ${ }^{6-9}$ However, the conventional method for extracting this flavonoid uses large volumes of organic solvent. Furthermore, this process is limited by long extraction times and low active compound levels. In ethanol extracts of mangkokan Leaf an average at $1.53 \%$, in ethyl fractions acetate an average at $4.79 \%$, and ethyl acetate extract at $1.64 \%$, ethyl acetate fraction at $5.83 \% .^{2-3}$

Several studies used ionic liquid (IL)-based microwave-assisted extraction (MAE), which has great advantages for extracting plant with high extraction levels and short extraction times..$^{10-11}$ The main advantages of MAE compared with conventional extraction techniques include the use of smaller amounts of solvents, lower costs and improved extraction quality because of the reduced degradation of thermolabile constituents. ${ }^{12-16}$
The use of 1-butyl-3-methylimidazolium bromide ([BMIM]Br), 1-butyl-3-methylimidazolium tetrafluoroborate ([BMIM] $\left.\mathrm{BF}_{4}\right), \quad$ 1-butyl-3methylimidazolium chloride ([BMIM]Cl), 1-butyl3-methylimidazolium hydrogen sulfate ([BMIM] $\mathrm{HSO}_{4}$ ), and 1-hexyl-3-methylimidazolium bromide ([HMIM]Br) as environment friendly solvents for extracting flavonoids from mangkokan leaves has never been reported. ILs are expected to represent safe alternatives to volatile organic solvents.

\section{MATERIALS AND METHODS}

\section{Herbal materials}

Mangkokan leaves were obtained from BALITRO, Bogor, West Java, Indonesia and analyzed by the Indonesian Institute of Sciences. The leaves were washed and dried in an oven, and the dried sample was crushed using a grinder.

\section{Chemical materials and equipment}

[BMIM]Br, [BMIM] BF, , [BMIM]Cl, [BMIM] $\mathrm{HSO}_{4}$ ), and [HMIM]Br were obtained from Shanghai Cheng Jie Chemical Co. LTD (China). Other chemicals used in this study included $\mathrm{NaHCO}_{3}$ (Merck, Germany), $\mathrm{K}_{2} \mathrm{HPO}_{4}$ (Merck, Germany), $\mathrm{NaCl}$ (Merck, Germany), ethyl acetate (Bratachem, Indonesia), methanol (Merck, Germany), glacial acetic acid (Merck, Germany), Aqua Pro Injection (PT. Ikapharmindo Putramas, Indonesia), quercetin standard (SigmaAldrich, Siangapore), and distilled water (CV. Satya Darmawan, Indonesia). The equipment used in the 
study included a UV-Vis spectrophotometer (Shimadzu, Japan), $900 \mathrm{~W}$ microwave (Buono MV-3002), VM-10 vortex mixer (WISD, Ireland), centrifuge (Laboratory Supply Company Ollmann \& Co, Germany), HPLC (Shimadzu, Japan), and TLC UV Scanner (Camag, Switzerland).

\section{Extraction methods}

One gram of the dried mangkokan leaf sample was placed in a boiling flask and mixed with ILs, followed by MAE. The operating conditions included a running time of $10 \mathrm{~min}$, IL concentration of $1.5 \mathrm{~mol}, 10$ $\mathrm{mL} / \mathrm{g}$ ratio, and power of $10 \mathrm{~W}$. The extracts were filtered using filter paper.

\section{Fractionation and separation with salt}

The filtrates were fractioned using ethyl acetate. The extract was separated using $0.01 \mathrm{~mol} / \mathrm{L} \mathrm{NaHCO}_{3}, \mathrm{~K}_{2} \mathrm{HPO}_{4}$, or $\mathrm{NaCl}$ (1:1 ratio). Each solution was vortexed for $20 \mathrm{~s}$ and then centrifuged for $15 \mathrm{~min}$ at 3000 $\mathrm{rpm}$. The organic phase containing quercetin was the top layer, which was dried in a water bath and hydrolyzed using $4 \mathrm{~N} \mathrm{HCl}$. The dried extract was weighed, diluted with deionized water to $5 \mathrm{~mL}$, and used for further analysis.

\section{Flavonoid identification}

Flavonoids were identified using TLC. Extracts were spotted on TLC plates using $5-\mu \mathrm{L}$ microcapillary tubes. Quercetin standard was used for comparison. Elution was conducted in a closed chamber that was already saturated with $\mathrm{n}$-hexane:ethyl acetate:acetic acid (7:2.5:0.5) as the mobile phase. The plate was dried, sprayed using $\mathrm{AlCl}_{3}$, and visualized under UV light for fluorescence. The $\mathrm{R} f$ value was calculated.

$R f=\frac{\text { the distance traveled by substance }}{\text { the distance traveled by solvent }}$

\section{Total flavonoid determination}

The total flavonoid contents of extracts were determined using quercetin as a standard. Various amounts of quercetin (up to $10 \mathrm{mg}$ ) were dissolved in $10 \mathrm{~mL}$ of methanol to prepare concentrations of 10-100 ppm to determine the linearity of quercetin standard. After preparing the extract, as much as $1 \mathrm{~mL}$ was removed and mixed with 3 $\mathrm{mL}$ of $96 \%$ methanol, $0.1 \mathrm{~mL}$ of $\mathrm{AlCl}_{3}, 0.1 \mathrm{~mL}$ of $1 \mathrm{M}$ sodium acetate, and $2.8 \mathrm{~mL}$ of double-distilled water. The solution was incubated at room temperature for $30 \mathrm{~min}$, and the absorbance was measured using a UV-Vis spectrophotometer at $410 \mathrm{~nm}$. The total flavonoid content was calculated from the calibration curve, and the results are presented as $\mathrm{mg} / \mathrm{g}$.

\section{Quercetin determination using HPLC}

The quercetin contents of the extracts were analyzed using HPLC. HPLC was performed in the isocratic mode using a C18 bonded-silica gel column $(5 \mu \mathrm{m}, 150 \times 4.6 \mathrm{~mm}$, GL Sciences, Japan $)$ and an LC-20AT HPLC system equipped with a UV-Vis detector (SPD-20A). The mobile phase was methanol:Aqua Pro Injection:glacial acetic acid (65:34:1). The UV detector wavelength was $370 \mathrm{~nm}$. The flow rate was $1 \mathrm{~mL} /$ min, the run time was $10 \mathrm{~min}$, and the injection volume was $20 \mu \mathrm{L}$. The sample was filtered using a 0.45 -micron syringe filter before analysis.

\section{RESULTS}

\section{Flavonoid identification}

The results of TLC analysis are presented in Figure 2. $\mathrm{R} f$ for each extract was compared with that of quercetin standard (0.38).

\section{Total flavonoid determination}

The standard solution was analyzed for linearity. A linear response was identified $\left(r^{2}=0.9955\right)$, and the equation was $y=0.0078 x-0.0052$. Extracts obtained using different ILs and three different salts were analyzed via UV-Vis spectrophotometry. The [BMIM] Cl extract using $\mathrm{NaCl}$ as the separation salt had the highest flavonoid content $(360.57$ $\mathrm{mg} / \mathrm{g}$ ), as shown in Table 2 .

\section{Quercetin determination using HPLC}

A linear response was observed $\left(y=65,196 x-270952, r^{2}=0.9998\right)$. The [BMIM] $\mathrm{BF}_{4}$ extract separated using $\mathrm{NaCl}$ exhibited the highest quercetin content among the solvents $(26.13 \mathrm{mg} / \mathrm{g})$, as shown in Table 3 . The chromatogram is presented in Figure 3.

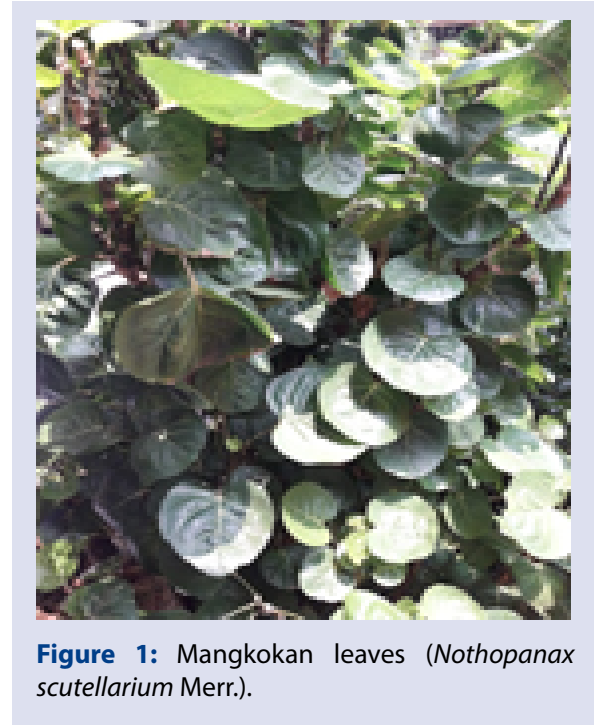




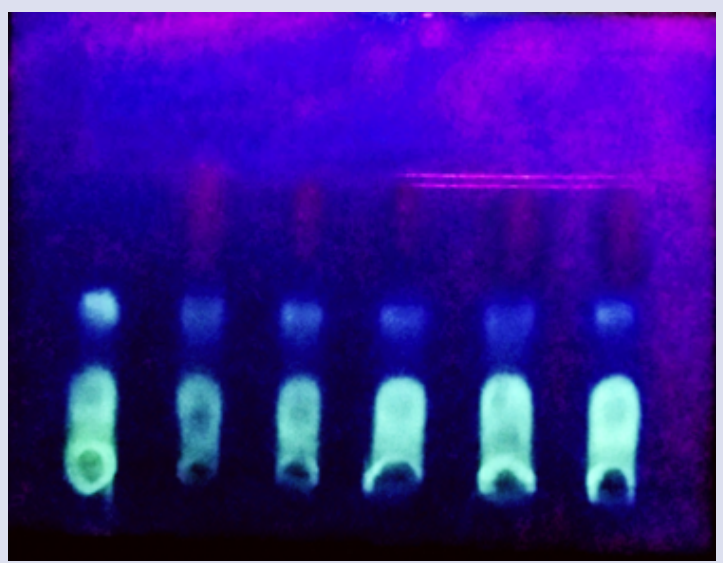

Figure 2: Flavonoid identification. The results are presented for (a) quercetin and the mangkokan leaf extracts using (b) 1-hexyl-3-methylimidazolium bromide, (c) 1-butyl-3-methylimidazolium hydrogen sulfate, (d) 1-butyl-3-methylimidazolium bromide, (e) 1-butyl-3-methylimidazolium chloride, and (f) 1-butyl-3methylimidazolium tetrafluoroborate as ionic liquids.
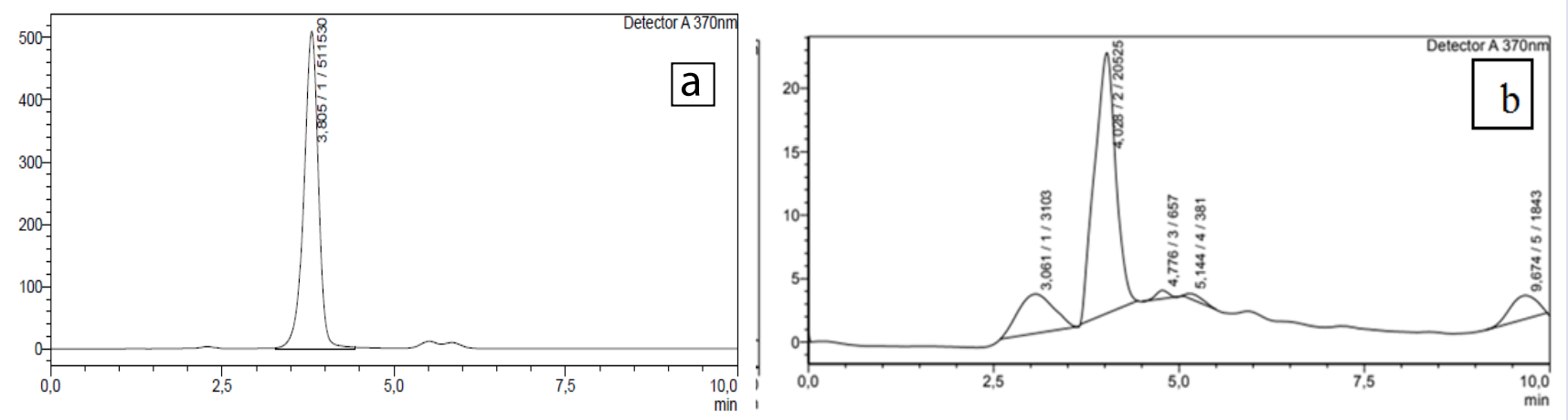

Figure 3: Chromatograms of (a) quercetin and (b) the 1-butyl-3-methylimidazolium tetrafluoroborate extract of mangkokan leaves.

Table 1: $R f$ values of mangkokan leaf extracts.

\begin{tabular}{cc}
\hline Mangkokan leaf extract & Rf \\
\hline$[\mathrm{BMIM}] \mathrm{Br}$ & 0,36 \\
{$[\mathrm{BMIM}] \mathrm{BF}_{4}$} & 0,38 \\
{$[\mathrm{BMIM}] \mathrm{Cl}$} & 0,36 \\
{$\left[\mathrm{BMIM}_{\mathrm{HSO}}\right.$} & 0,36 \\
{$[\mathrm{HMIM}] \mathrm{Br}$} & 0,38 \\
\hline
\end{tabular}

Note: $[\mathrm{BMIM}] \mathrm{Br}$ is 1-butyl-3-methylimidazolium bromide, [BMIM]BF ${ }_{4}$ is 1-butyl-3methylimidazolium tetrafluoroborate, $[\mathrm{BMIM}] \mathrm{Cl}$ is 1-butyl-3-methylimidazolium chloride, [BMIM] $\mathrm{HSO}_{4}$ is 1-butyl-3-methylimidazolium hydrogen sulfate, [HMIM] Br is 1-hexyl-3methylimidazolium bromide. 
Table 2: Effect of ionic liquids and salt addition on the total flavonoid content.

\begin{tabular}{|c|c|}
\hline Extract & Total flavonoid content $(\mathrm{mg} / \mathrm{g})$ \\
\hline$[\mathrm{BMIM}] \mathrm{Br}+\mathrm{NaHCO}_{3}$ & $19.79 \pm 0.33$ \\
\hline$[\mathrm{BMIM}] \mathrm{Br}+\mathrm{NaCl}$ & $23.09 \pm 0.21$ \\
\hline$[\mathrm{BMIM}] \mathrm{Br}+\mathrm{K}_{2} \mathrm{HPO}_{4}$ & $28.94 \pm 0.32$ \\
\hline$[\mathrm{BMIM}] \mathrm{Cl}+\mathrm{NaHCO}_{3}$ & $325.36 \pm 8.48$ \\
\hline$[\mathrm{BMIM}] \mathrm{Cl}+\mathrm{NaCl}$ & $354.2 \pm 6.38$ \\
\hline$[\mathrm{BMIM}] \mathrm{Cl}+\mathrm{K}_{2} \mathrm{HPO}_{4}$ & $204.09 \pm 2.14$ \\
\hline$[\mathrm{BMIM}] \mathrm{BF}_{4}+\mathrm{NaHCO}_{3}$ & $148.79 \pm 1,85$ \\
\hline$[\mathrm{BMIM}] \mathrm{BF}_{4}+\mathrm{NaCl}$ & $337.12 \pm 8.06$ \\
\hline$[\mathrm{BMIM}] \mathrm{BF}_{4}+\mathrm{K}_{2} \mathrm{HPO}_{4}$ & $149.09 \pm 9.62$ \\
\hline$[\mathrm{BMIM}] \mathrm{HSO}_{4}+\mathrm{NaHCO}_{3}$ & $88, .8 \pm 2.74$ \\
\hline$[\mathrm{BMIM}] \mathrm{HSO}_{4}+\mathrm{NaCl}$ & $74.67 \pm 1.64$ \\
\hline$[\mathrm{BMIM}] \mathrm{HSO}_{4}+\mathrm{K}_{2} \mathrm{HPO}_{4}$ & $113.44 \pm 0.61$ \\
\hline$[\mathrm{HMIM}] \mathrm{Br}+\mathrm{NaHCO}_{3}$ & $42.33 \pm 0.14$ \\
\hline$[\mathrm{HMIM}] \mathrm{Br}+\mathrm{NaCl}$ & $57.19 \pm 1.57$ \\
\hline$[\mathrm{HMIM}] \mathrm{Br}+\mathrm{K}_{2} \mathrm{HPO}_{4}$ & $66.62 \pm 1.22$ \\
\hline
\end{tabular}

Table 3: Effect of ionic liquids and salts addition on quercetin content.

\begin{tabular}{|c|c|}
\hline Extract & Quercetin content $(\mathrm{mg} / \mathrm{g}) \pm \mathrm{SD}$ \\
\hline$[\mathrm{BMIM}] \mathrm{Br}+\mathrm{NaHCO}_{3}$ & $4.03 \pm 0.33$ \\
\hline$[\mathrm{BMIM}] \mathrm{Br}+\mathrm{NaCl}$ & $3.67 \pm 0.21$ \\
\hline$[\mathrm{BMIM}] \mathrm{Br}+\mathrm{K}_{2} \mathrm{HPO}_{4}$ & $8.53 \pm 0.32$ \\
\hline$[\mathrm{BMIM}] \mathrm{Cl}+\mathrm{NaHCO}_{3}$ & $12.9 \pm 8.48$ \\
\hline$[\mathrm{BMIM}] \mathrm{Cl}+\mathrm{NaCl}$ & $22.6 \pm 6.38$ \\
\hline$[\mathrm{BMIM}] \mathrm{Cl}+\mathrm{K}_{2} \mathrm{HPO}_{4}$ & $6,41 \pm 2,14$ \\
\hline$[\mathrm{BMIM}] \mathrm{BF}_{4}+\mathrm{NaHCO}_{3}$ & $11.96 \pm 1.85$ \\
\hline$[\mathrm{BMIM}] \mathrm{BF}_{4}+\mathrm{NaCl}$ & $26.13 \pm 8.06$ \\
\hline$[\mathrm{BMIM}] \mathrm{BF}_{4}+\mathrm{K}_{2} \mathrm{HPO}_{4}$ & $24.62 \pm 9.62$ \\
\hline$[\mathrm{BMIM}] \mathrm{HSO}_{4}+\mathrm{NaHCO}_{3}$ & $2.33 \pm 2.74$ \\
\hline$[\mathrm{BMIM}] \mathrm{HSO}_{4}+\mathrm{NaCl}$ & $3.08 \pm 1.64$ \\
\hline$[\mathrm{BMIM}] \mathrm{HSO}_{4}+\mathrm{K}_{2} \mathrm{HPO}_{4}$ & $4.92 \pm 0.61$ \\
\hline$[\mathrm{HMIM}] \mathrm{Br}+\mathrm{NaHCO}_{3}$ & $2.99 \pm 0.14$ \\
\hline$[\mathrm{HMIM}] \mathrm{Br}+\mathrm{NaCl}$ & $4.34 \pm 1.57$ \\
\hline$[\mathrm{HMIM}] \mathrm{Br}+\mathrm{K}_{2} \mathrm{HPO}_{4}$ & $1.86 \pm 1.22$ \\
\hline
\end{tabular}

\section{DISCUSSION}

Mangkokan leaves were extracted via ILMAE, and the extracts were fractionated using ethyl acetate. ILs have non-volatile characteristics. Organic solvents such as ethyl acetate can be used to separate nonvolatile compounds. ${ }^{17}$ Then, the extracts were separated using different salts. This process precipitates residues in ILs, resulting in significant increases in extraction yields. ${ }^{18}$

The determination of the total flavonoid content was conducted by a colorimetric method using a UV-Vis spectrophotometer. In this study, the highest flavonoid content in mangkokan leaf extract was achieved using [BMIM]Cl, whereas [BMIM] $\mathrm{BF}_{4}$ provided the highest quercetin content. This could be attributable to the presence of other flavonoid contents or differences in the principle of analysis, but further research is needed to clarify this issue. UV-Vis spectrophotometry is one of the most widely used methods for the determination of total flavonoid content because of its low implementation costs and availability in the laboratory. ${ }^{19-20}$ However, HPLC is a more sensitive and selective analytical procedure for measuring isolated compounds, and it is widely used for all classes of flavonoids. ${ }^{20}$

The use of [BMIM] $\mathrm{BF}_{4}$ for the success extraction of natural products was previously reported. ${ }^{21-22}$ This finding is attributable to the fact that ILs can be used as both polar and non-polar solvents. ${ }^{23}$ ILs can also be used in inorganic, organic, and polymer-solvent systems. ${ }^{24}$ In addition, ILs are more environmentally benign solvents than the volatile organic solvents commonly used for extraction..$^{25}$ From this study, anion and cation is strongly influence an extraction result. Different anion and cation were studied and differences in their extraction yield were readily apparent, as shown in Table 3 . The results showed that the ionic liquids based on $\mathrm{Cl}^{-}$were the more efficient for total flavonoid, with $\mathrm{BF}_{4}$ - being the most efficient for quercetin. The different of cations including $\mathrm{Bmim}+$ and $\mathrm{Hmim}+$ were evaluated and the results are shown in Table 3. The extraction yield decreased when the alkyl chain length of the cation was increased from butyl to hexyl. The results suggested that the increasing alkyl chain length influences the extraction yield. Proton acidity and hydrophobicity for cations increased from buthyl to hexyl at the 1-position of the 1-alkyl-3-methylimidalizium ring. Both the proper hydrogen bonding and hydrophobic interactions of Bmim+ resulted in stronger solvation interactions with flavonoids followed by higher extraction yields than $[\mathrm{Hmim}]^{+}$.

The different of salt using in partition affects extraction yields that different for each ionic liquids. Sodium cloride obtains the highest extraction quercetin compared with other salt in mangkokan leaves extraction using [BMIM] $\mathrm{BF}_{4}$ solvent. Each ionic liquids has different optimum partition salt. It is because the mechanism of the saltingout effect is very complex due to the interplay of different types of 
interaction between the solutes and the solvent. Hydration theories and the related water-structuring effects (kosmotropy) and semiquantitative way the intensity of the salting-out effects.

There were several factors that affect ionic liquid in this extraction process that has not been conducted in this study; extraction time and microwave power, temperature, and plant characteristics that must be consider for further study. The quantity of the extracted compound can be increased by increasing the extraction time, but it increase the risks of thermolable component. ${ }^{26}$ The extraction time and microwave power was very sensitive parameters and both was needed to be handled simultaneously. ${ }^{27} \mathrm{~A}$ combination of low or medium power with longer exposure is generally chosen to optimize MAE procedures, but study showed that various strengths from $500 \mathrm{~W}$ to $1000 \mathrm{~W}$ have no significant effect on flavonoid yields. ${ }^{26}$ Temperatures in the range $60-90{ }^{\circ} \mathrm{C}$ have been used most often in MAEs carried out at atmospheric pressure. ${ }^{27}$ The choice of extraction temperature depends on the stability and extraction results of the active compound target. Sample characteristics affect MAE performance. The small particle size will cause difficulties in separating the extract from the residue and additional cleaning steps may have to be used. In addition, fine samples treated with solvents for 90 minutes before extraction can improve MAE heating efficiency, increase diffusion and increase the mass transfer of active compounds to the solvent. However, in a number of reported cases, a long pretreatment time did not improve the extraction results because the active ingredients might have left the sample matrix before extraction. ${ }^{28}$

\section{CONCLUSIONS}

The highest quercetin content was observed for mangkokan leaves extracted using [BMIM] $\mathrm{BF}_{4}$ combined with $\mathrm{NaCl}$ as the separation salt $(26.13 \mathrm{mg} / \mathrm{g})$, confirming its utility for extracting quercetin from this medicinal plant.

\section{ACKNOWLEDGEMENTS}

This research was supported by Directorate General of Higher Education, Ministry of Education dan Culture, Republic of Indonesia via Hibah Riset Penulisan Tesis Magister.

\section{CONFLICTS OF INTEREST}

None.

\section{REFERENCES}

1. Arief H. Tumbuhan Obat dan Khasiatnya Seri 2. Jakarta: Penebar Swadaya. 2008.

2. Rifkia V, Jufri M, Mun'im A. Hair Growth Promoting Activity of Nothopanax scutellarium Merr. Leaves. J Young Pharm. 2017; pp 436-440.

3. Jufri M, Amelia L, Mun'im A. Hair Growth Activity and Safety Test of Ethosomal Gel Ethyl Acetate Fraction of Nothopanax Leaves (Nothopanax scutellarium, Merr.). Asian J Pharm Clin Res. 2017; 10 (8).

4. Handojo Y. Stability Test and Physical Activity White Rat Hair Growth Gel Extracts of preparations mangkokan (Nothopanax Scutellarium Merr). Thesis, University of Indonesia, Depok, Indonesia. 2011.

5. Miean KH, Mohamed S. Flavonoid (myricetin, quercetin, kaempferol, luteolin, and apigenin) content of edible tropical plants. J Agric Food Chem. 2001; 49: 3106-3112.

6. Sérgio DCJ, João VOS, Luís AAC, Marcela AP, Nereide SSM, Isabella MFC. Antibacterial and antibiofilm activities of quercetin against clinical isolates of Staphyloccocus aureus and Staphylococcus saprophyticus with resistance profile. International Journal of Environment, Agriculture, and Biotechnology. 2018; 2456-1878. Available from: https://ijeab.com/detail/antibacterial-andantibiofilm-activities-of-quercetin-against-clinical-isolates-of-staphyloccocusaureus-and-staphylococcus-saprophyticus-with-resistance-profile/
7. Salvamani S, Gunasekaran B, Shaharuddin NA, Ahmad SA, Shukor MY Antiartherosclerotic effects of plant flavonoids. Biomed Res Int, 2014; 480258. Available from: https://www.hindawi.com/journals/bmri/2014/480258/

8. Endale M, Park SC, Kim S, Kim SH, Yang Y, Cho JY, Rhee MH. Quercetin disrupts tyrosine-phosphorylated phosphatidylinositol 3-kinase and myeloid differentiation factor-88 association, and inhibits MAPK/AP-1 and IKK/ NF-kB-induced inflammatory mediators production in RAW 264.7 cells. Immunobiology. 2013; 218: 1452-1467.

9. Sultana B, Anwar F. Flavonols (Kaempeferol, quercetin, myricetin) contents of selected fruits, vegetables and medicinal plants. Food Chem. 2008; 108 : 879-84.

10. Zhang Q, Zhao SH, Chen J, Zhang LW. Application of ionic liquid-based microwave-assisted extraction of flavonoids from Scutellaria baicalensis Georgi. J Chromatogr B Analyt Technol Biomed Life Sci. 2015; 1002: 411-7.

11. Sónia PMV, Francisca AES, Maria VQ, Dibyendu M, Mara GF, João APC Ionic-Liquid-Mediated Extraction and Separation Processes for Bioactive Compounds: Past, Present, and Future Trends. Chem Rev. 2017; 117 (10) 6984-7052.

12. Waziiroh E, Harijono, Kamilia K. Microwave-assisted extraction (MAE) of bioactive saponin from mahogany seed (Swietenia mahogany Jacq) International Conference on Green Agro-industry and Bioeconomy. IOP Conf. Series: Earth and Environmental Science; 24-25 October 2017, Batu City, East Java, Indonesia. 2018.

13. Hoang VC, Minh HN, Paul DR, John BG, Sophie EP. Microwave-assisted extraction and ultrasound-assisted extraction for recovering carotenoids from Gac peel and their effects on antioxidant capacity of the extracts. Food Sci Nutr. 2018; 6(1):189-196.

14. Nor HA, Zulkifly A. Microwave-Assisted Extraction of Phenolic Compound From Pineapple Skins: The Optimum Operating Condition and Comparison with Soxhlet Extraction. Malaysian Journal of Analytical Sciences. 2017; 21(3); $690-699$.

15. Afoakwah AN, Owusu J, Adomako C, Teye E. Microwave Assisted Extraction (MAE) of Antioxidant Constituents in Plant Materials. Global Journal of Biochemistry and Biotechnology. 2012: 1(2): 132-140.

16. Loredana S, Maria NM, Valeria P, Giuseppe R, Maria AS, Claudia DG et al. Antioxidant Activity and Phenolic Content of Microwave-Assisted Solanum melongena Extracts. The Scientific World Journal. 2014: 719486. Available from: https://www.ncbi.nlm.nih.gov/pmc/articles/PMC3934095/

17. Mai NL, Ahn K, Koo Y. Methods for recovery of ionic liquids: a review. Process Biochemistry. 2014; 49; 872-881.

18. Tanfidz A, Abdul M, Mahdi J. Optimization of Imidazolium-Based lonic LiquidMicrowave Assisted Extraction for Oxyresveratrol Extraction from Morus alba Roots. J Young Pharm. 2018; 10(3): pp 272-275.

19. Ya Y, Yuzhi W, Ran X, Meidong H, Huan Z. Application of ionic liquids in the microwaveassisted extraction of podophyllotoxin from Chinese herbal medicine. Analyst. 2011; 136: 2294-2305.

20. Lombard, Geoffriau, Peffley. Flavonoid quantification in onion by spectrophotometric and High Performance Liquid Chromatography analysis. Hortscience.2002; (37): 682-685.

21. Zhang LY, Lou ZX, Kou XR, Ke YQ, Jia QH., He G.H et al. Study on ultrasonic and microwave synergistic extraction of total flavonoids and scopolamine from Dendrobium nobile Lindera. J Chin Med Mater. 2017; 152-157.

22. Xu JJ, Yang R, Ye LH, Cao J, Cao W, Hu SS, Peng LQ. Application of ionic liquids for elution of bioactive flavonoid glycosides from lime fruit by miniaturized matrix solid-phase dispersion. Food Chem. 2016; 204: 167-175.

23. Tan ZJ, Li FF, Xu XL, Xing JM. Simultaneous extraction and purification of aloe polysaccharides and proteins using ionic liquid based aqueous two-phase system coupled with dialysis membrane. Desalination. 2012; 286: 389-393.

24. Flieger J, Zelazko, Anna C. Ionic Liquids in Separation Techniques. Applications of Ionic Liquids in Science and Technology. InTech; 2011.

25. Han D, Row, Kyung $H$. Recent Applications of lonic Liquids in Separation Technology. Molecules, 2010; 15: 2405-2426.

26. Tatke P, Jaiswal Y. An Overview of Microwave Assisted Extraction and its Applications in Herbal Drug Research, Research Journal of Medicinal Plants, 2011.

27. Harneet KK, Rajendra, Kamal KS, Roshni T, Vivekananda M. Critical analysis of research trends and issues in microwave assisted extraction of phenolics: Have we really done enough, Trends in Analytical Chemistry, 2016; 85.

28. Chan $\mathrm{CH}$, Yusoff R, Ngoh GC, Lee FW, Kung. Microwave-assisted extractions of active ingredients from plants., Journal of Chromatography $A, 2011 ; 121$ 


\section{GRAPHICAL ABSTRACT}

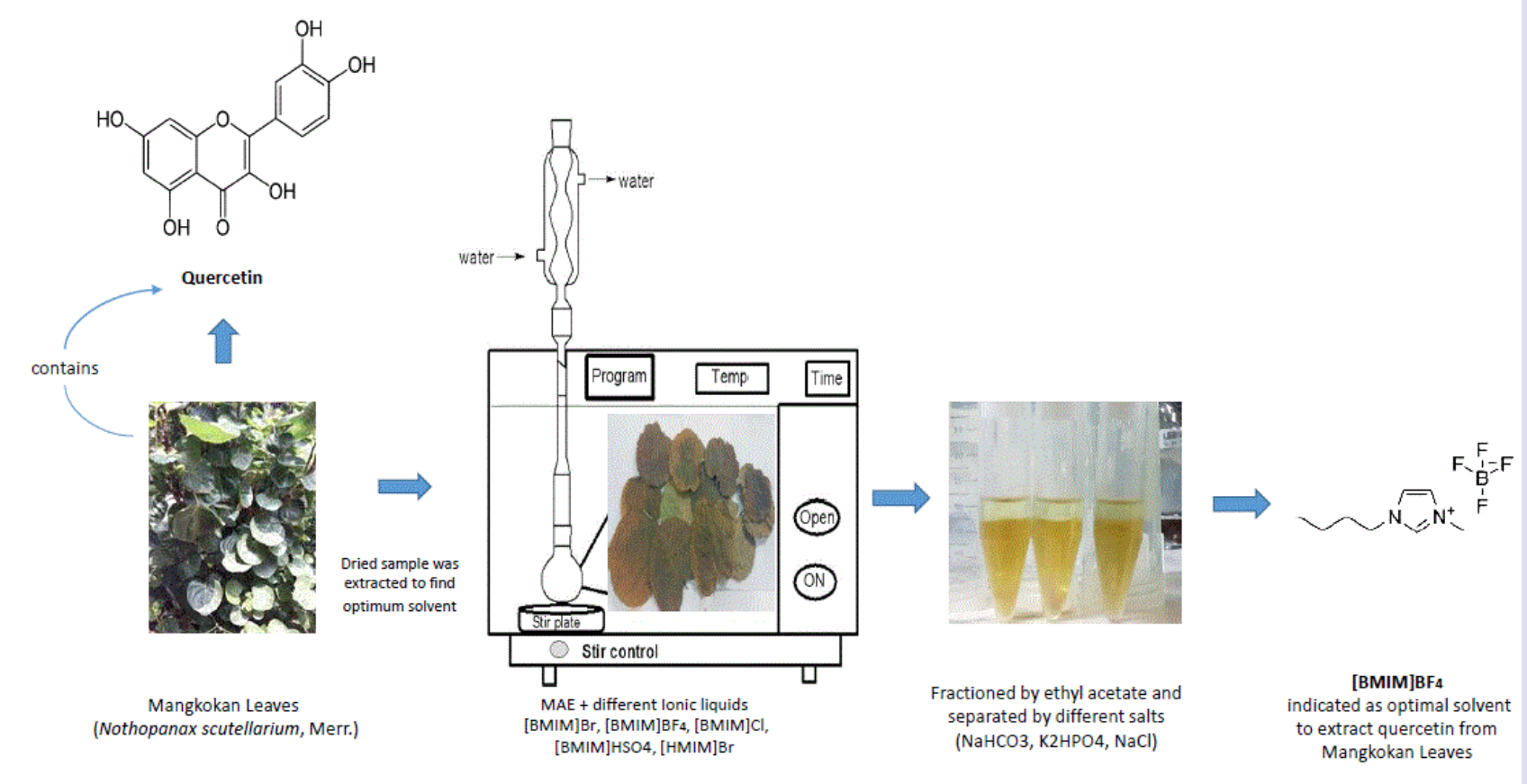

\section{ABOUT AUTHORS}

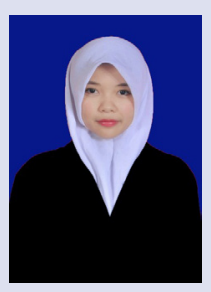

Ika Aulia Rahmi was graduated of herbal magister program at Faculty of Pharmacy, Universitas Indonesia. She has conducted research on pharmacognosy and pharmaceutical technology.

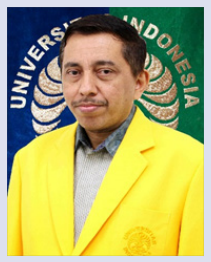

Mahdi Jufri is lecturer at Department Pharmaceutical Technology and Drug Development, Faculty of Pharmacy, Universitas Indonesia. He works in pharmaceutical technology and drug development.

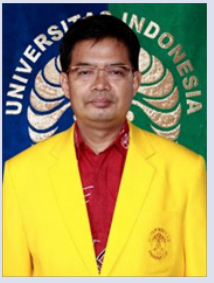

Abdul Mun'im is Professor at Department Pharmacognosy and Phytochemistry, Faculty of Pharmacy, Universitas Indonesia. He works in the area on Pharmacognosy and Phytochemistry especially working in drugs discovery of herbal and extraction technology. He also conducted research in metabolie profiling, structure elucidation etc.

Cite this article: Rahmi IA, Jufri M, Mun'im A. Extraction of Quercetin from Nothopanax scutellarium Leaves via lonic Liquid-based Microwave-assisted Extraction. Pharmacogn J. 2020;12(6)Suppl:1512-7. 